\title{
Cutting Edge Data on Immunology
}

\section{The latest information on progress in immunological reseach with particular relevance to allergy - that is what the audience can expect on Sept. 15th at 2 p.m. at the EAACI/DGAI Joint Symposium „Immune Regulation of Allergic Inflammation“.}

Or Wednesday afternoon at 2 p.m., right at the beginning of the Allergy Congress 2004 in Aachen will be an international kick off symposium on the „Immune Regulation of Allergic Inflammation". The event is a joint effort of the Immunology Sections of the German Society for Allergology and Clinical Immunology (DGAI) and the European Academy of Allergology and Clinical Immunology (EAACI) to bring together members of both societies.

Eminent national and international scientists will present and discuss novel concepts and cutting edge data of cellular and molecular mechanisms involved in allergic inflammation. Topics covered will be allergen carriers, pathogens, mucosal Langerhans cells, dendritic cells, regulatory $T$ cells as modulators of allergic inflammation. The symposium is of interest for allergists of all disciplines, allergists in training, and graduate and postgraduate students involved in allergy research.
Invited speakers for the joint symposium are:

- Cezmi Akdis, Davos, Switzerland (EAACI)

- Thomas Bieber, Bonn, Germany (DGAI)

- Thilo Jakob, Munich, Germany (DGAI/EAACI)

— Joachim Saloga, Mainz, Germany (DGAI)

— Frederica Sallusto, Bellinzona, Switzerland (EAACI)

- Annika Scheynius, Lund, Sweden (EAACI)

On behalf of the DGAI and EAACI Immunology Sections I cordially invite you to participate in what is promising to be a very exciting event right at the beginning of the Allergy Congress 2004 in Aachen.

Priv.-Doz. Dr. Thilo Jakob, Munich Secretary of the EAACI Immunology

Section
Immunology Section of the

DGAl and EAACI

The aims of the Immuno-

logy Section of the DGAI

and $\mathrm{EAACl}$ are:

— to promote understanding of the etiology of allergic diseases and of mechanisms of basic and clinical immunology

— to foster the communication between basic immunology and clinical allergy

— to encourage training in basic immunology for young investigators, physician-scientists, and physicians

— to disseminate the latest information regarding progress in immunological research with particular relevance to allergy.

The objective of the immunology section of both societies is to encourage membership from relevant areas such as basic and clinical immunology and allergy, to relate to European and national societies of immunology and to promote an understanding of the importance of allergy within those societies, to advise national boards and the EEC on matters of policy within the area of basic and clinical immunology and allergy, to advise the scientific program committee on the development of relevant programmes, to promote Europe-wide cooperation in scientific and clinical research in the relevant areas, and to suggest task forces and scientific sessions within their areas.

- EAACI website: www.eaaci.net

— DGAI website: www.dgaki.de

\section{Allergie-Kongress Aachen 2004 auf einen Blick}

\section{Veranstalter}

Ärzteverband Deutscher Allergologen (ÄDA), Deutsche Gesellschaft für Allergologie und klinische Immunologie (DGAl) und Gesellschaft für Pädiatrische Allergologie und Umweltmedizin (GPA)

\section{Kongressorganisation}

Service Systems GbR

Carin Fresle und Ursula Raab

Blumenstraße 14, 63303 Dreieich

Tel.: (оo 49-61 ०3) 63657

Fax: (0о 49-61 03) 67674

E-Mail: aeda@sersys.de

\section{Tagungspräsidenten}

Univ.-Prof. Dr. med. Hans F. Merk, Dr. med. Frank Friedrichs

Kongressbüro Aachen
Kinderärztliche Praxisgemeinschaft
Aachen-Laurensberg
Elke Dovern
Rathausstraße 10, 52072 Aachen
Tel.: (oo 49-2 41) 171096
Fax: (0o 49-2 41) 174349
E-Mail: dovern@kinderarztpraxis-
laurensberg.de

\section{Kongressbüro Aachen}

Kinderärztliche Praxisgemeinschaft

Aachen-Lau

Rathausstraße 10, 52072 Aachen

Tel.: (oo 49-2 41) 171096

laurensberg.de

\section{Vorprogramm}

Das offizielle Vorprogramm des Allergie-Kongresses 2004 kann bei der Kongressorganisation kostenlos angefordert werden.

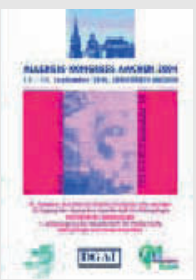

Internet

www.allergie-kongress-2004.de 